THE READERS OF NOVYI MIR 



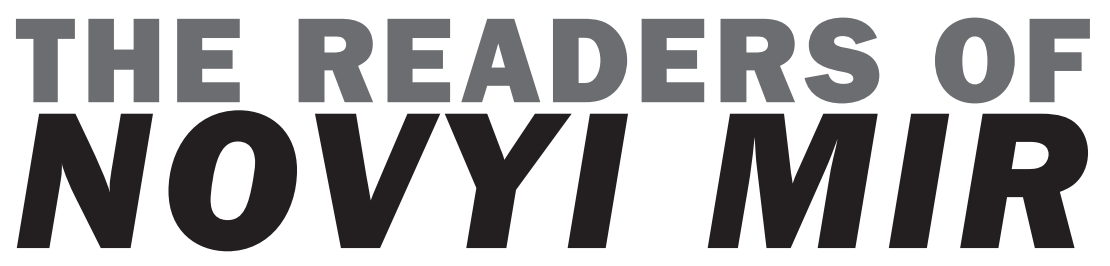

Coming to Terms with the Stalinist Past

\section{DENIS KOZLOV}

HARVARD UNIVERSITY PRESS

Cambridge, Massachusetts, and London, England 2013 
Copyright (C) 2013 by the President and Fellows of Harvard College

ALL RIGHTS RESERVED

Printed in the United States of America

\section{Library of Congress Cataloging-in-Publication Data}

Kozlov, Denis, 1973-

The readers of Novyi Mir : coming to terms with the Stalinist past / Denis Kozlov.

pages; $\mathrm{cm}$

Includes bibliographical references and index.

ISBN 978-o-674-07287-9 (alk. paper)

1. Literature and society-Soviet Union. 2. Reader-response criticismSocial aspects-Soviet Union. 3. Authors and readers-Soviet Union.

4. Novyi mir-History. 5. Russian periodicals-Soviet Union-History.

6. Russian literature-Social aspects-Soviet Union. 7. Terror in literature.

8. Terror-Soviet Union-Public opinion. 9. Soviet Union-History-

Public opinion. I. Title.

$\mathrm{PG}_{3022 . K 692} 2013$

$$
\text { 891.709'0044-dc23 } 2012044170
$$


Посвящается моему деду, Августу Моисеевичу Шерешевскому, и бабушке, Алле Давыдовне Шерешевской, которые все это пережили. 
